\title{
$\alpha$-Amylase and $\alpha$-Glucosidase Inhibitory Activities of Chemical Constituents from Wedelia chinensis (Osbeck.) Merr. Leaves
}

\author{
Nguyen Phuong Thao $\mathbb{D}^{1},{ }^{1}$ Pham Thanh Binh, ${ }^{1}$ Nguyen Thi Luyen, ${ }^{1,2}$ Ta Manh Hung, ${ }^{3}$ \\ Nguyen Hai Dang, ${ }^{1,2}$ and Nguyen Tien Dat $\mathbb{D}^{2,4}$ \\ ${ }^{1}$ Advanced Center for Bio-Organic Chemistry, Institute of Marine Biochemistry (IMBC), Vietnam Academy of Science and \\ Technology (VAST), 18 Hoang Quoc Viet, Caugiay, Hanoi, Vietnam \\ ${ }^{2}$ Graduate University of Science and Technology, VAST, 18 Hoang Quoc Viet, Caugiay, Hanoi, Vietnam \\ ${ }^{3}$ National Institute of Drug Quality Control (NIDQC), 48 Hai Ba Trung, Hoankiem, Hanoi, Vietnam \\ ${ }^{4}$ Center for Research and Technology Transfer, VAST, 18 Hoang Quoc Viet, Caugiay, Hanoi, Vietnam
}

Correspondence should be addressed to Nguyen Phuong Thao; thaonp@imbc.vast.vn

Received 12 February 2018; Accepted 4 April 2018; Published 9 May 2018

Academic Editor: Federica Pellati

Copyright (C) 2018 Nguyen Phuong Thao et al. This is an open access article distributed under the Creative Commons Attribution License, which permits unrestricted use, distribution, and reproduction in any medium, provided the original work is properly cited.

As part of an ongoing search for new natural products from medicinal plants to treat type 2 diabetes, two new compounds, a megastigmane sesquiterpenoid sulfonic acid (1) and a new cyclohexylethanoid derivative (2), and seven related known compounds (3-9) were isolated from the leaves of Wedelia chinensis (Osbeck.) Merr. The structures of the compounds were conducted via interpretation of their spectroscopic data (1D and 2D NMR, IR, and MS), and the absolute configurations of compound 1 were determined by the modified Mosher's method. The $\mathrm{MeOH}$ extract of W. chinensis was found to inhibit $\alpha$-amylase and $\alpha$-glucosidase inhibitory activities as well as by the compounds isolated from this extract. Furthermore, compound 7 showed the strongest effect with $\mathrm{IC}_{50}$ values of $112.8 \pm 15.1 \mathrm{~g} / \mathrm{mL}$ (against $\alpha$-amylase) and $785.9 \pm 12.7 \mathrm{~g} / \mathrm{mL}$ (against $\alpha$-glucosidase). Compounds $\mathbf{1}, \mathbf{8}$, and $\mathbf{9}$ showed moderate $\alpha$-amylase and $\alpha$-glucosidase inhibitory effects. Other compounds showed weak or did not show any effect on both enzymes. The results suggested that the antidiabetic properties from the leaves of $W$. chinensis are not simply a result of each isolated compound but are due to other components such as the accessibility of polyphenolic groups to $\alpha$-amylase and $\alpha$-glucosidase activities.

\section{Introduction}

In recent years, the number of diabetic patients is rapidly rising in most parts of the world, especially in developing Southeast Asian countries $[1,2]$. The control of blood glucose concentrations near the normal range is mainly based on the use of oral hypoglycaemic/antihyperglycaemic agents and insulin. However, all of these treatments have limited efficacy and are associated with undesirable side effects [3, 4], leading to increasing interest in the use of medicinal plants for the alternative management of type 2 diabetes mellitus. An effective suggestion for type 2 diabetes management is the inhibition of $\alpha$-glucosidase and $\alpha$-amylase [5].

Natural health-care products derived from medicinal plants or herbs have been developed as alternative or complementary treatments for many common disorders [6]. Several medicinal plants have been the useful sources of novel biologically active compounds. Many pharmaceutical agents have been discovered by screening natural products from plants, many of which have been developed as new leads for pharmaceuticals [7]. Predominantly herbal drugs have been widely used globally for diabetic treatment over thousands of years due to their traditional acceptability and lesser side effects. Therefore, screening of $\alpha$-amylase $(1,4-$ $\alpha$-D-glucan glucanohydrolases; EC. 3.2.1.1) and $\alpha$-glucosidase ( $\alpha$-D-glucoside glucohydrolase, EC 3.2.1.20) inhibitors in medicinal plants has received much attention $[6,7]$.

Among the traditionally used important medicinal plants, the genus Wedelia (Asteraceae) contains approximately 107 species in the world, and among them, about 6 species are in 
Vietnam. They are all herbal plants and distributed in tropical and subtropical regions of Asia and Pacific Islands [8]. Wedelia chinensis (Osbeck.) Merr. (Asteraceae) is a deciduous shrub, widely distributed in several Asian countries such as China, Japan, and mainland Vietnam. The leaves, stems, and fruits of this species have been traditionally used in fold medicine for the treatment of chin cough, diarrhoea, diphtheria, faucitis, hemorrhoids, and injuries due to falls, jaundice, and pertussis and are often consumed as tea in the form of infusion [9]. Phytochemically, up to date, a number of secondary metabolites have been identified, including various types of compounds belonging to chemical classes of flavonoids, diterpenoids, and triterpenoids. Besides, several other compounds including common saponins and phytosterol derivatives were also reported in the species, but they appear to have a more limited distribution. Recently, several studies have demonstrated the exploration of pharmacological potential, such as analgesic [10], androgen-suppressing [11], anticancer $[12,13]$, antibacterial, anticonvulsant, antifungal [14], antioxidant [13], anti-inflammatory [10, 15], antiosteoprotic [16], antiulcerogenic, antistress [17], hepatoprotective [18], and sedative activities [19]. However, the investigation about the chemical constituents of $W$. chinensis is not sufficient compared to the other plants in the genus Wedelia.

As part of an ongoing search for new biologically active natural products from Vietnamese medicinal plants, we found that a $\mathrm{MeOH}$ extract of $W$. chinensis leaves showed significant in vitro $\alpha$-amylase and $\alpha$-glucosidase inhibitory activities. Previously, there have been no reports on either the extracts or isolated components from this species against $\alpha$-amylase and $\alpha$-glucosidase activities. Reported herein are the isolation and structural elucidation of a new megastigmane sesquiterpenoid sulfonic acid (1), a new cyclohexylethanoid derivative (2), and 7 known compounds (3-9) as well as the evaluation of $\alpha$-amylase and $\alpha$-glucosidase activities.

\section{Materials and Methods}

2.1. General Experimental Procedures. Optical rotations were measured using a JASCO P-2000 polarimeter (JASCO, Oklahoma, OK, US). IR spectra were obtained on a Bruker TENSOR 37 FT-IR spectrometer (Bruker, Billerica, MA, USA). The ${ }^{1} \mathrm{H}$ and ${ }^{13} \mathrm{C}$, HMQC, HMBC, NOESY/ROESY, and COSY NMR spectra were recorded on a $500 \mathrm{MHz}$ Bruker DRX spectrometer (Bruker, Tupper Hall, CA, USA), and the chemical shift $(\delta)$ was expressed in ppm with reference to the TMS signals. The HRESIMS were obtained using an Agilent 6550 iFunnel Q-TOF LC/MS system (Emeryville, CA, USA). Medium-pressure liquid chromatography (MPLC) was carried out on a BiotageIsolera One system. Column chromatography (CC) was conducted using 65-250 or 230-400 mesh silica gel (Sorbent Technologies, Atlanta, GA, USA), porous polymer gel (Diaion ${ }^{\circledR}$ HP-20, 20-60 mesh, Mitsubishi Chemical, Tokyo, Japan), Sephadex ${ }^{\mathrm{TM}}$ LH-20 (Supelco, Bellefonte, PA, USA), octadecyl silica (ODS, $50 \mu \mathrm{m}$, Cosmosil $140 \mathrm{C}_{18}-\mathrm{OPN}$, Nacalai Tesque), and YMC RP-C 18 resins $(30-50 \mu \mathrm{m}$, Fuji
Silysia Chemical). Analytical thin-layer chromatography (TLC) systems were performed on precoated silica gel $60 \mathrm{~F}_{254}$ plates (1.05554.0001, Merck) and RP-18 $\mathrm{F}_{254 \mathrm{~S}}$ plates (1.15685.0001, Merck), and the isolated compounds were visualized by spraying with $10 \% \mathrm{H}_{2} \mathrm{SO}_{4}$ in water and then heating for 1.5-2 minutes. All procedures were carried out with solvents purchased from commercial sources, which were used without further purification.

2.2. Plant Material. The leaves of $W$. chinensis (Osbeck.) Merr. were collected from Ba Dinh, Ha Noi, Vietnam, in April 2017 and taxonomically identified by Professor Tran Huy Thai (Institute of Ecology and Biological Resources). A voucher specimen (NCCB-2016.55.01) was deposited at the Herbarium of Institute of Marine Biochemistry and Institute of Ecology and Biological Resources, Vietnam Academy of Science and Technology.

2.3. Compounds. From the methanolic extract of $W$. chinensis, 9 compounds (1-9) were isolated and structurally elucidated. Stock solutions of tested compounds in DMSO were prepared kept at $-20^{\circ} \mathrm{C}$ and diluted to the final concentration in fresh media before each experiment. To not affect the cell growth, the final DMSO concentration did not exceed $0.5 \%$ in all experiments.

2.4. Extraction and Isolation. The dried leaves of $W$. chinensis $(4.4 \mathrm{~kg})$ were cut into pieces and extracted with $95 \%$ aqueous $\mathrm{MeOH}(3 \times 6.5 \mathrm{~L})$ under ultrasonic agitation at $90 \mathrm{~Hz}$. The methanol solution was removed of solvent under a vacuum and was filtered through a Büchner funnel to produce a dried brown extract ( $160 \mathrm{~g}, \mathrm{~A})$. Since the $\mathrm{MeOH}$ extract significantly reduced $\alpha$-amylase and $\alpha$-glucosidase inhibitory activities, it was suspended in distilled water and partitioned between EtOAc $(1 \mathrm{~L} \times 3)$ to obtain EtOAc $(16.9 \mathrm{~g}, \mathrm{~B})$ and aqueous soluble fractions $(\mathrm{W})$.

The EtOAc fraction was separated on silica gel MPLC (column: Biotage ${ }^{\circledR}$ SNAP Cartridge, KP-SIL, $340 \mathrm{~g}$ ) using the mobile phase of $n$-hexane-acetone (gradient 30:70, 50:50, $70: 30,0: 100,15 \mathrm{~mL} / \mathrm{min}, 90 \mathrm{~min}$ ) to give six fractions (B-1 to B-6). This MPLC procedure was repeated 5 times using the same conditions before further isolation. Fraction B-3 was chromatographed by Sephadex ${ }^{\circledR}$ LH-20 CC $(\Phi 25 \mathrm{~mm}, \mathrm{~L}$ $1250 \mathrm{~mm}$ ) eluted with acetone- $\mathrm{H}_{2} \mathrm{O}$ (gradient 95:5, 70:30, $50: 50, \mathrm{v} / \mathrm{v}$ ) to give three subfractions (B-3.1 to B-3.3) and further purified by YMC RP-C ${ }_{18} \mathrm{CC}(\Phi 15 \mathrm{~mm}, \mathrm{~L} 700 \mathrm{~mm})$ using acetone- $\mathrm{H}_{2} \mathrm{O}(1: 2)$ as the eluent to pomonic acid (8, crystalline powder, $11.2 \mathrm{mg})$ and pomolic acid (9, crystalline powder, $15.4 \mathrm{mg})$. Next, fraction B-6 was chromatographed over a silica gel CC $(\Phi 12 \mathrm{~mm}, \mathrm{~L} 600 \mathrm{~mm})$ eluted with $n$ hexane-EtOAc $(2: 1)$ to obtain jaceosidin (7, pale yellow crystals, $56.8 \mathrm{mg}$ ).

The $\mathrm{H}_{2} \mathrm{O}$ fraction was separated using a Diaion HP-20 column ( $\Phi 100 \mathrm{~mm}, \mathrm{~L} 500 \mathrm{~mm})$ and was eluted with a gradient solvent mixture of $\mathrm{MeOH}-\mathrm{H}_{2} \mathrm{O}$ (gradient $25: 75,50$ : $50,65: 35,75: 25$, to pure $\mathrm{MeOH}$, stepwise) to yield five fractions (W-1 to $\mathrm{W}-5)$, based on TLC analysis. The 
Table 1: ${ }^{1} \mathrm{H}$ and ${ }^{13} \mathrm{C}$ NMR spectroscopic data of $\mathbf{1}$ and 2 in $\mathrm{CD}_{3} \mathrm{OD}$.

\begin{tabular}{|c|c|c|c|c|}
\hline \multirow{2}{*}{ Position } & \multicolumn{2}{|c|}{1} & \multicolumn{2}{|r|}{2} \\
\hline & $\delta_{\mathrm{C}}{ }^{\mathrm{a}}$ & $\delta_{\mathrm{H}}^{\mathrm{b}}$ mult. $(J$ in $\mathrm{Hz})$ & $\delta_{\mathrm{C}}{ }^{\mathrm{a}}$ & $\delta_{\mathrm{H}}^{\mathrm{b}}$ mult. $(J$ in $\mathrm{Hz})$ \\
\hline 1 & $35.5, \mathrm{C}$ & - & $79.4, \mathrm{C}$ & - \\
\hline 2 & $37.9, \mathrm{CH}_{2}$ & $\begin{array}{c}1.47 \mathrm{dd}(3.5,12.5) \\
1.84 \mathrm{t}(12.5)\end{array}$ & $83.3, \mathrm{CH}$ & $4.00 \mathrm{dd}(6.0,9.5)$ \\
\hline 3 & $75.5, \mathrm{CH}$ & 4.60 ddd $(3.0,3.5,12.5)$ & $37.5, \mathrm{CH}_{2}$ & $\begin{array}{c}1.39 \mathrm{dd}(6.0,13.5) \\
1.80 \mathrm{~m}\end{array}$ \\
\hline 4 & $71.6, \mathrm{CH}$ & $4.27 \mathrm{dd}(1.0,3.0)$ & $75.4, \mathrm{C}$ & - \\
\hline 5 & 69.4, C & - & 29.2, $\mathrm{CH}_{2}$ & $\begin{array}{c}1.53 \text { ddd }(4.5,9.5,13.5) \\
1.66 \mathrm{~m}\end{array}$ \\
\hline 6 & 71.3, C & - & $30.5, \mathrm{CH}_{2}$ & $\begin{array}{l}1.93 \text { ddd }(4.0,11.5,13.5) \\
2.09 \text { ddd }(4.0,7.5,13.5)\end{array}$ \\
\hline 7 & $125.6, \mathrm{CH}$ & $5.92 \mathrm{dd}(1.0,16.5)$ & 36.0, $\mathrm{CH}_{2}$ & $\begin{array}{l}1.76 \text { ddd }(4.0,8.0,12.5) \\
2.22 \text { ddd }(8.0,9.5,12.5)\end{array}$ \\
\hline 8 & $139.3, \mathrm{CH}$ & $5.69 \mathrm{dd}(6.0,16.5)$ & $66.4, \mathrm{CH}_{2}$ & $\begin{array}{c}3.95 \text { ddd }(3.0,8.0,9.5) \\
4.05 \text { dd }(8.0,8.5)\end{array}$ \\
\hline 9 & $68.5, \mathrm{CH}$ & $4.31 \mathrm{dd}(6.0,12.5)$ & $74.3, \mathrm{CH}$ & $3.51 \mathrm{q}(6.5)$ \\
\hline 10 & 23.7, $\mathrm{CH}_{3}$ & $1.24 \mathrm{~d}(6.0)$ & $17.0, \mathrm{CH}_{3}$ & $1.15 \mathrm{~d}(6.5)$ \\
\hline 11 & $24.8, \mathrm{CH}_{3}$ & $1.03 \mathrm{~s}$ & - & - \\
\hline 12 & $29.5, \mathrm{CH}_{3}$ & $1.13 \mathrm{~s}$ & - & - \\
\hline 13 & $17.1, \mathrm{CH}_{3}$ & $1.28 \mathrm{~s}$ & - & - \\
\hline
\end{tabular}

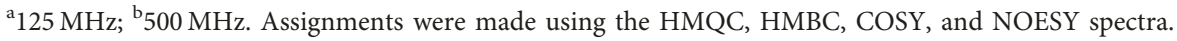

fractionation W-4 was separated via silica gel CC $(\Phi 30 \mathrm{~mm}$, $\mathrm{L} 750 \mathrm{~mm})$ and eluted repeatedly with $\mathrm{CH}_{2} \mathrm{Cl}_{2}-\mathrm{MeOH}(0 \rightarrow$ $100 \%)$ to yield five subfractions (W-4.1 to W-4.5). Subfraction W-4.1 was subjected to a silica gel CC $(\Phi 20 \mathrm{~mm}, \mathrm{~L}$ $800 \mathrm{~mm}$ with a solvent mixture of $\left.\mathrm{CH}_{2} \mathrm{Cl}_{2}-\mathrm{MeOH}, 9: 1\right)$ and passed over a Sephadex LH-20 column ( $\Phi 15 \mathrm{~mm}, \mathrm{~L} 950 \mathrm{~mm})$ and then through an open YMC RP- $\mathrm{C}_{18}$ silica gel column $\left(\Phi 15 \mathrm{~mm}, \mathrm{~L} 800 \mathrm{~mm}, 65 \rightarrow 100 \%, \mathrm{H}_{2} \mathrm{O}-\mathrm{MeOH}\right)$ to afford wednenol (2, colorless oil, $12.5 \mathrm{mg})$, cleroindicin E (3, colorless oil, $15.2 \mathrm{mg}$ ), and rengyol (4, white solid, $46.6 \mathrm{mg}$ ). Finally, when the same steps were repeated as above, wednenic (1, white powder, $10.6 \mathrm{mg}$ ), cornoside (5, brown oil, $28.7 \mathrm{mg})$, and benzyl $\beta$-D-glucopyranoside- 2 -sulfate (6, amorphous white powder, $86.1 \mathrm{mg}$ ) were also obtained by purifying subfraction $\mathrm{W}-4.5$ on $\mathrm{YMC} \mathrm{RP}-\mathrm{C}_{18}$ silica gel ( $\Phi 20 \mathrm{~mm}, \mathrm{~L} 700 \mathrm{~mm}$ ) and followed by passing over a Sephadex LH-20 column ( $\Phi 15 \mathrm{~mm}, \mathrm{~L} 900 \mathrm{~mm})$ using mixtures of $\mathrm{MeOH}-\mathrm{H}_{2} \mathrm{O}(1: 5)$.

2.5. Physical and Spectroscopic Data of Compounds. Wednenic (1): white powder; $[\alpha]_{D}^{24}-26.5$ (c 0.25, MeOH); IR $\nu_{\max }(\mathrm{KBr}) 3395,2968,2930,1648,1580,1511,1372,1226$, 1163,1075 , and $1040 \mathrm{~cm}^{-1}$; HRESIMS (positive-ion mode) $m / z 345.0987[\mathrm{M}+\mathrm{H}]^{+}$(cald. for $\mathrm{C}_{13} \mathrm{H}_{23} \mathrm{O}_{7} \mathrm{~S}, 345.0984$ ) and $367.0801[\mathrm{M}+\mathrm{Na}]^{+}$(cald. for $\mathrm{C}_{13} \mathrm{H}_{22} \mathrm{NaO}_{7} \mathrm{~S}, 367.0803$ ) and (negative-ion mode) $\mathrm{m} / z 225.1482\left[\mathrm{M}-\mathrm{SO}_{4} \mathrm{Na}\right]^{-}$(cald. for $\left.\mathrm{C}_{13} \mathrm{H}_{21} \mathrm{O}_{3}, 225.1490\right)$; for ${ }^{1} \mathrm{H} \mathrm{NMR}\left(\mathrm{CD}_{3} \mathrm{OD}, 500 \mathrm{MHz}\right)$ and ${ }^{13} \mathrm{C}$ NMR $\left(\mathrm{CD}_{3} \mathrm{OD}, 125 \mathrm{MHz}\right)$ spectroscopic data, see Table 1.

Wednenol (2): colorless oil; $[\alpha]_{D}^{24}-47.2$ (c 0.22, MeOH); IR $\nu_{\max }(\mathrm{KBr}) 3341,2950,1455,1270,1168$, and $920 \mathrm{~cm}^{-1}$; HRESIMS (positive-ion mode) $m / z 185.1170[\mathrm{M}+\mathrm{H}]^{+}$(cald. for $\left.\mathrm{C}_{10} \mathrm{H}_{17} \mathrm{O}_{3}, 185.1177\right)$; for ${ }^{1} \mathrm{H}$ NMR $\left(\mathrm{CD}_{3} \mathrm{OD}, 500 \mathrm{MHz}\right)$ and ${ }^{13} \mathrm{C} \mathrm{NMR}\left(\mathrm{CD}_{3} \mathrm{OD}, 125 \mathrm{MHz}\right)$ spectroscopic data, see Table 1.
Benzyl $\beta$-D-glucopyranoside-2-sulfate (6): amorphous white powder; $[\alpha]_{D}^{24} 60.8$ (c 0,25, MeOH); IR $\nu_{\max }(\mathrm{KBr})$ : 3595, 3100, 2952, 2850, 1647, 1575, 1511, 1362, 1228, 1153, 1055 , and $1010 \mathrm{~cm}^{-1}$; ESIMS (negative-ion mode) $\mathrm{m} / z$ 349, $[\mathrm{M}-\mathrm{H}]^{-} ;{ }^{1} \mathrm{H}$ NMR $\left(500 \mathrm{MHz}, \mathrm{CD}_{3} \mathrm{OD}\right): \delta_{\mathrm{H}} 3.31(1 \mathrm{H}, \mathrm{m}$, $\left.\mathrm{H}-5^{\prime}\right), 3.44\left(1 \mathrm{H}, \mathrm{t}, J=9.0 \mathrm{~Hz}, \mathrm{H}-3^{\prime}\right), 3.66(1 \mathrm{H}, \mathrm{t}, J=9.0 \mathrm{~Hz}$, $\left.\mathrm{H}-4^{\prime}\right), 3.71\left(1 \mathrm{H}, \mathrm{d}, J=1.5,12.0 \mathrm{~Hz}, \mathrm{H}-6^{\prime} \mathrm{b}\right), 3.91(1 \mathrm{H}, \mathrm{d}$, $\left.J=1.5,12.0 \mathrm{~Hz}, \mathrm{H}-6^{\prime} \mathrm{a}\right), 4.17\left(1 \mathrm{H}, \mathrm{t}, J=8.0 \mathrm{~Hz}, \mathrm{H}-2^{\prime}\right), 4.53$ $\left(1 \mathrm{H}, \mathrm{d}, J=7.5 \mathrm{~Hz}, \mathrm{H}-1^{\prime}\right), 4.74(1 \mathrm{H}, \mathrm{d}, J=12.0 \mathrm{~Hz}, \mathrm{H}-7 \mathrm{~b}), 4.93$ $(1 \mathrm{H}, \mathrm{d}, J=12.0 \mathrm{~Hz}, \mathrm{H}-7 \mathrm{a}), 7.25(1 \mathrm{H}, \mathrm{d}, J=7.5 \mathrm{~Hz}, \mathrm{H}-4), 7.33$ $(2 \mathrm{H}, \mathrm{d}, J=7.5 \mathrm{~Hz}, \mathrm{H}-3$ and $\mathrm{H}-5)$, and $7.47(2 \mathrm{H}, \mathrm{br} \mathrm{t}$, $J=7.5 \mathrm{~Hz}, \mathrm{H}-2$ and $\mathrm{H}-6) ;{ }^{13} \mathrm{C} \mathrm{NMR}\left(125 \mathrm{MHz}, \mathrm{CD}_{3} \mathrm{OD}\right): \delta_{\mathrm{C}}$ 138.9 (C-1), 128.8 (C-2 and C-6), 129.1 (C-3 and C-5), 128.4 (C-4), and $71.5(\mathrm{C}-7)$; Glc: $101.0\left(\mathrm{C}-1^{\prime}\right), 81.4\left(\mathrm{C}-2^{\prime}\right), 77.4(\mathrm{C}-$ $\left.3^{\prime}\right), 71.5\left(\mathrm{C}-4^{\prime}\right), 77.6\left(\mathrm{C}-5^{\prime}\right)$, and $62.6\left(\mathrm{C}-6^{\prime}\right)$.

2.6. Preparation of (S)- and (R)-MTPA Ester Derivatives of 1. Compound $1(3.0 \mathrm{mg})$ was dissolved in $2.5 \mathrm{~mL}$ of anhydrous $\mathrm{CH}_{2} \mathrm{Cl}_{2}$. Dimethylaminopyridine $(35 \mathrm{mg})$, triethylamine, and $(R)$-MTPA chloride $(30 \mu \mathrm{L})$ were then added in sequence. The reaction mixture was stirred for $3 \mathrm{~h}$ at room temperature and then quenched by the addition of $1 \mathrm{~mL}$ of aqueous $\mathrm{MeOH}$. The solvents were removed under vacuum, and the residue was passed through a small silica gel column using $\mathrm{CH}_{2} \mathrm{Cl}_{2}-\mathrm{MeOH}(100: 1)$ as the eluent to provide the $(S)$-MTPA ester of $\mathbf{1}$ (1a, $1.2 \mathrm{mg}$ ). The $(R)$-MTPA derivative (1b, $1.5 \mathrm{mg}$ ) was prepared with $(S)$-MTPA chloride and purified in the same manner.

(S)-MTPA ester derivative of 1 (1a): $1 \mathrm{H} \cdot \mathrm{NMR}$ (CD3OD, $500 \mathrm{MHz}): \delta_{\mathrm{H}} 7.613-7.421(10 \mathrm{H}$, overlap, aromatic protons), $3.630(3 \mathrm{H}, \mathrm{s}, \mathrm{OCH} 3), 1.501(1 \mathrm{H}, \mathrm{dd}, J=3.5,12.5 \mathrm{~Hz}, \mathrm{H}-2 \mathrm{a})$, $1.859(1 \mathrm{H}, \mathrm{t}, J=12.5 \mathrm{~Hz}, \mathrm{H}-2 \mathrm{~b}), 4.693(1 \mathrm{H}, \mathrm{dt}, J=3.5$, $12.5 \mathrm{~Hz}, \mathrm{H}-3), 5.767(1 \mathrm{H}, \mathrm{d}, J=3.5 \mathrm{~Hz}, \mathrm{H}-4), 6.418(1 \mathrm{H}, \mathrm{dd}$, $J=1.0,16.5 \mathrm{~Hz}, \mathrm{H}-7), 5.901(1 \mathrm{H}, \mathrm{dd}, J=6.0,16.5 \mathrm{~Hz}, \mathrm{H}-8)$, $5.983(1 \mathrm{H}, \mathrm{dd}, J=6.0,12.5 \mathrm{~Hz}, \mathrm{H}-9), 1.431(3 \mathrm{H}, \mathrm{d}, J=6.0 \mathrm{~Hz}$, 
H-10), 1.202 (3 H, s, H-11), 1.050 (3 H, s, H-12), and 1.315 (3 H, s, H-13).

(R)-MTPA ester derivative of $\mathbf{1}(\mathbf{1 b})$ : $1 \mathrm{H} \cdot \mathrm{NMR}(\mathrm{CD} 3 \mathrm{OD}$, $500 \mathrm{MHz}): \delta_{\mathrm{H}} 7.613-7.401(10 \mathrm{H}$, overlap, aromatic protons), $3.58(3 \mathrm{H}, \mathrm{s}, \mathrm{OCH} 3), 1.516(1 \mathrm{H}, \mathrm{dd}, J=3.5,12.5 \mathrm{~Hz}, \mathrm{H}-2 \mathrm{a})$, $1.878(1 \mathrm{H}, \mathrm{t}, J=12.5 \mathrm{~Hz}, \mathrm{H}-2 \mathrm{~b}), 4.676(1 \mathrm{H}, \mathrm{dt}, J=3.5$, $12.5 \mathrm{~Hz}, \mathrm{H}-3), 5.767(1 \mathrm{H}, \mathrm{d}, J=3.5 \mathrm{~Hz}, \mathrm{H}-4), 6.395(1 \mathrm{H}, \mathrm{dd}$, $J=1.0,16.5 \mathrm{~Hz}, \mathrm{H}-7), 5.846(1 \mathrm{H}, \mathrm{dd}, J=6.0,16.5 \mathrm{~Hz}, \mathrm{H}-8)$, $5.982(1 \mathrm{H}, \mathrm{dd}, J=6.0,12.5 \mathrm{~Hz}, \mathrm{H}-9), 1.463(3 \mathrm{H}, \mathrm{d}, J=6.0 \mathrm{~Hz}$, $\mathrm{H}-10), 1.174(3 \mathrm{H}, \mathrm{s}, \mathrm{H}-11), 1.014(3 \mathrm{H}, \mathrm{s}, \mathrm{H}-12)$, and 1.328 (3 H, s, H-13).

2.7. Assay for $\alpha$-Amylase Inhibition. The porcine pancreas $\alpha$-amylase (A3176, Sigma-Aldrich) enzyme inhibitory activity was carried out according to the standard method with minor modifications [20-22]. The substrate was prepared by boiling $100 \mathrm{mg}$ potato starch in $5 \mathrm{~mL}$ phosphate buffer $(\mathrm{pH}$ 7.0) for $5 \mathrm{~min}$ and then cooling to room temperature. The sample ( $2 \mathrm{~mL}$ dissolved in DMSO) and substrate $(50 \mathrm{~mL})$ were mixed in $30 \mathrm{~mL}$ of $0.1 \mathrm{M}$ phosphate buffer ( $\mathrm{pH} 7.0$ ). After $5 \mathrm{~min}$ preincubation, $5 \mathrm{mg} / \mathrm{mL} \alpha$-amylase solution $(20 \mathrm{~mL})$ was added, and the solution was incubated at $37^{\circ} \mathrm{C}$ for $15 \mathrm{~min}$. The reaction was stopped by adding $50 \mathrm{~mL}$ of $1 \mathrm{M} \cdot \mathrm{HCl}$, and then, $50 \mathrm{~mL}$ of iodine solution was added. The absorbances were measured at $650 \mathrm{~nm}$ by a microplate reader. Acarbose was used as a positive control. The inhibitory activity was calculated by the following equation: $\alpha$-amylase inhibitory activity $(\%)=(1-\mathrm{A} / \mathrm{A} 0) \times 100$, where A is the absorbance of the sample and $\mathrm{A} 0$ is the absorbance of the blank, respectively. The $\mathrm{IC}_{50}$ value was calculated by GraphPad Prism.

2.8. Assay for $\alpha$-Glucosidase Inhibition. The yeast $\alpha$-glucosidase (G0660, Sigma-Aldrich) inhibition assay was performed using the substrate $p$-nitrophenyl- $\alpha$-D-glucopyranoside according to the previously described method [21-23]. Briefly, samples and acarbose were prepared by dissolving at $2 \mathrm{mg} / \mathrm{mL}$ (with extracts) or $0.8 \mathrm{mM}$ (with pure compound) in DMSO, and $0.5 \mathrm{U} / \mathrm{mL} \alpha$-glucosidase $(40 \mathrm{~mL})$ was mixed in $120 \mathrm{~mL}$ of $0.1 \mathrm{M}$ phosphate buffer (pH 6.8). After $5 \mathrm{~min}$ preincubation, $5 \mathrm{mM}$ p-nitrophenyl- $\alpha$-D-glucopyranoside solution $(40 \mathrm{~mL})$ was added, and the solution was incubated at $37^{\circ} \mathrm{C}$ for $30 \mathrm{~min}$. Pipette the following reagents into a 96-well plate. Each concentration of samples was carried out in triplicate. The absorbance of released 4-nitrophenol was measured at $405 \mathrm{~nm}$ by using a microplate reader (xMark, Bio-Rad, USA). Acarbose was used as the positive control. The inhibitory activity was calculated by the following equation: $\alpha$-glucosidase inhibitory activity $(\%)=(1-\mathrm{A} / \mathrm{A} 0) \times 100$, where $\mathrm{A}$ is the absorbance of the sample and $\mathrm{A} 0$ is the absorbance of the blank, respectively. The $\mathrm{IC}_{50}$ value was calculated by GraphPad Prism.

2.9. Data Expression and Statistical Analysis. Data were expressed as mean value \pm standard deviation (SD) of blood glucose. Data were evaluated using two-way ANOVA followed by Dunnett's multiple comparison test, and groups were considered significantly different if $P<0.05$. All data are presented as mean $\pm \mathrm{SD}$.

\section{Results and Discussion}

3.1. Identification of Compounds 1-9. A $\mathrm{MeOH}$ extract from the leaves of $W$. chinensis was suspended in $\mathrm{H}_{2} \mathrm{O}$ and fractionated successively with EtOAc-soluble fraction, and then, each fraction was evaluated for $\alpha$-amylase and $\alpha$-glucosidase activities. The EtOAc-soluble fraction and water layer were chosen for subsequent studies, which resulted in the isolation of two new compounds (1-2), together with seven known compounds (3-9; Figure 1). Moreover, compounds 1-6 were reported for the first time from this species and from the genus Wedelia.

Wednenic (1) was obtained as a white powder with a negative optical rotation $\left([\alpha]_{\mathrm{D}}^{24}-26.5, c 0.25, \mathrm{MeOH}\right)$, and the molecular formula, $\mathrm{C}_{13} \mathrm{H}_{22} \mathrm{O}_{7} \mathrm{~S}$, was determined by HRESIMS, with a protonated molecular ion peak at $\mathrm{m} / \mathrm{z}$ $345.0987[\mathrm{M}+\mathrm{H}]^{+}$and a sodium adduct molecular ion peak at $m / z 367.0801[\mathrm{M}+\mathrm{Na}]^{+}$. The fragment ion peak at $\mathrm{m} / z$ $225.1482\left[\mathrm{M}-\mathrm{SO}_{4} \mathrm{Na}\right]^{-}$in the (-)HRESIMS spectrum showed the presence of a sulfate group in $\mathbf{1}$. A detailed assessment of the NMR data indicated that $\mathbf{1}$ is a megastigmane, a compound class known as components of plant species.

The ${ }^{1} \mathrm{H}$ NMR spectrum (Table 1 ) of $\mathbf{1}$ exhibited signals for four methyl groups $\left[\delta_{\mathrm{H}} 1.24(\mathrm{~d}, J=6.0 \mathrm{~Hz}, \mathrm{H}-10), 1.03\right.$ (s, H-11), 1.13 (s, H-12), and 1.28 (s, H-13)], a pair of methylene protons $\left[\delta_{\mathrm{H}} 1.47(\mathrm{dd}, J=3.5,12.5 \mathrm{~Hz}, \mathrm{H}-2 \mathrm{a})\right.$ and $1.84(\mathrm{t}, J=12.5 \mathrm{~Hz}, \mathrm{H}-2 \mathrm{~b})]$, three oxygenated methines $\left[\delta_{\mathrm{H}}\right.$ 4.60 (ddd, $J=3.0,3.5,12.5 \mathrm{~Hz}, \mathrm{H}-3), 4.27$ (dd, $J=1.0$, $3.0 \mathrm{~Hz}, \mathrm{H}-4)$, and $4.31(\mathrm{dd}, J=6.0,12.5 \mathrm{~Hz}, \mathrm{H}-9)]$, and two olefinic protons $\left[\delta_{\mathrm{H}} 5.92(\mathrm{dd}, J=1.0,16.5 \mathrm{~Hz}, \mathrm{H}-7)\right.$ and 5.69 (dd, $J=6.0,16.5 \mathrm{~Hz}, \mathrm{H}-8)$ ]. The larger coupling constant $(J=16.5 \mathrm{~Hz})$ between $\mathrm{H}-7$ and $\mathrm{H}-8$ indicates that the geometry of the $\Delta^{7}$ double bond is $E$. The ${ }^{13} \mathrm{C}$ NMR and DEPT spectra (Table 1) showed 13 carbon signals of four methyls [ $\delta_{\mathrm{C}} 23.7(\mathrm{C}-10), 24.8$ (C-11), 29.5 (C-12), and 17.1 (C$13)]$, a methylene $\left[\left(\delta_{\mathrm{C}} 37.9(\mathrm{C}-2)\right]\right.$, an oxygenated methine bearing a sulfate group $\left[\delta_{\mathrm{C}} 75.5(\mathrm{C}-3)\right]$, two oxygenated methines $\left[\delta_{\mathrm{C}} 71.6(\mathrm{C}-4)\right.$ and $\left.68.5(\mathrm{C}-9)\right]$, and three nonprotonated carbons $\left[\delta_{\mathrm{C}} 35.5(\mathrm{C}-1), 69.4(\mathrm{C}-5)\right.$, and 71.3 (C$6)]$, together with a pair of trans-olefinic methine carbons $\left[\delta_{\mathrm{C}} 125.6(\mathrm{C}-7)\right.$ and $\left.139.3(\mathrm{C}-8)\right]$. Based on these data, a megastigmane sesquiterpenoid sulfonic acid has been determined for $\mathbf{1}$.

Interpretation of the COSY and HSQC spectra of $\mathbf{1}$ revealed the presence of two partial structures, "C-2/C3/C4" and "C-7/C-8/C-9/C-10" (Figure 2). These two partial structures were connected through a nonprotonated carbon (C-6) on the basis of HMBC correlations of $\mathrm{H}-4, \mathrm{H}-7, \mathrm{H}-8$, $\mathrm{H}-12$, and $\mathrm{H}-13$ to $\mathrm{C}-6$. The $\mathrm{HMBC}$ correlations from $\mathrm{H}_{3}-11$ and $\mathrm{H}_{3}-12$ to $\mathrm{C}-1, \mathrm{C}-2$, and $\mathrm{C}-6$ indicated that $\mathrm{C}-2, \mathrm{C}-11$, C-12, and C-6 were all connected with C-1. The chemical shifts and coupling constants of 1 were in good agreement with those of $(3 S, 4 S, 5 R, 6 S, 9 S, 7 E)$-megastigman-7ene-5,6epoxy-3,4,9-triol 9-O- $\beta$-D-glucopyranoside recorded in the same deuterated solvent [24] but quite different from the data of the C-4. The substitution at C-3 and C-4 was 


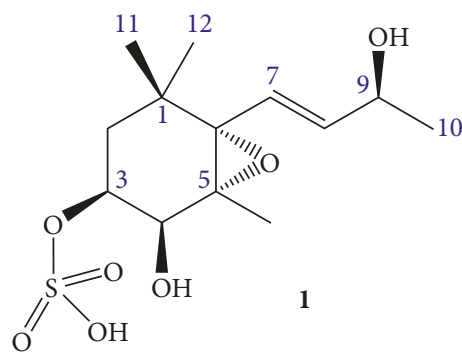

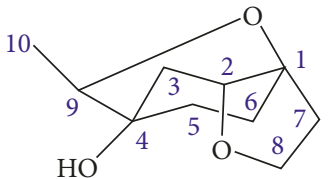

2<smiles>OC1CC2CCC(O)(C1)C2</smiles>

3<smiles>OCC[C@]1(O)CC[C@@H](O)CC1</smiles>

4<smiles>O=C1C=CC(O)(CCOC(OCCO)[C@H](O)[C@H](O)CO)C=C1</smiles><smiles>O=S(=O)(O)O[C@H](OCc1ccccc1)[C@H](O)[C@H](O)CO</smiles><smiles>COc1cc(-c2cc(=O)c3c(O)c(OC)c(O)cc3o2)ccc1O</smiles>

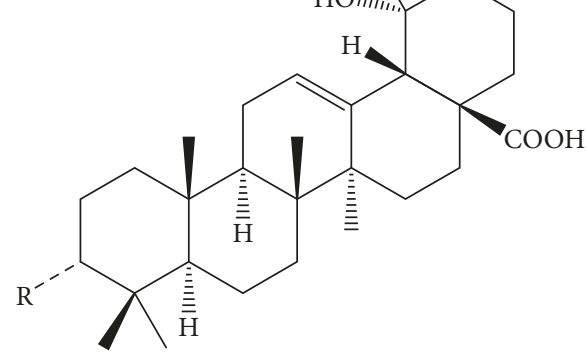

$8 \mathrm{R}=\mathrm{O} \quad 9 \mathrm{R}=\beta \mathrm{OH}$

Figure 1: Structures of compounds 1-9 isolated from $W$. chinensis.
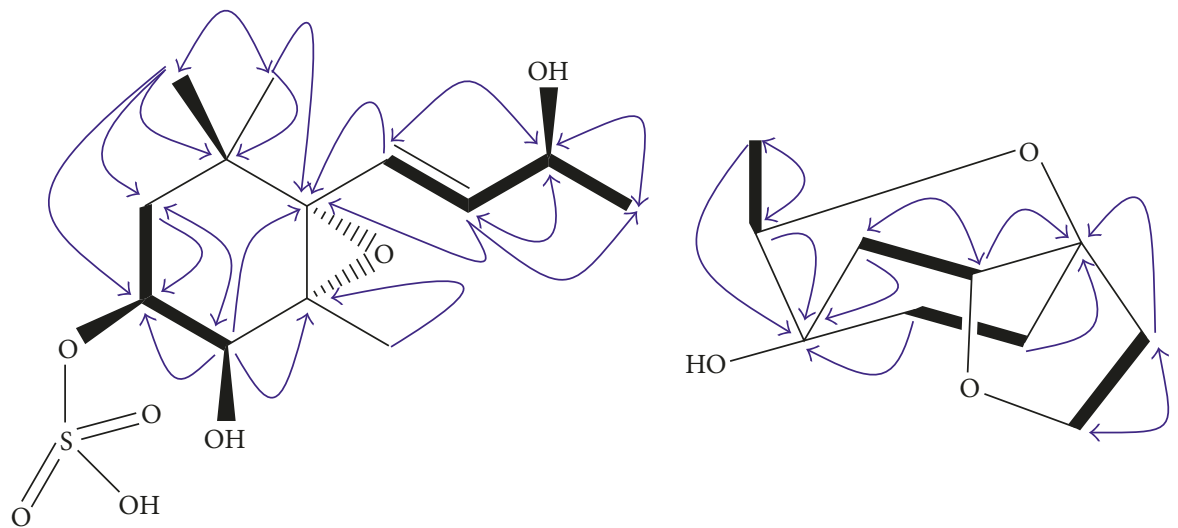

Figure 2: Key HMBC $(\longrightarrow)$ and COSY correlations of 1 and 2.

tentatively identified as a sulfonate group and a hydroxyl group based on the HMBC correlations, which supported the total structure of $\mathbf{1}$ (Figure 2).

The relative configuration of $\mathbf{1}$ was deduced from analysis of coupling constants and the NOESY spectrum (except for C-9), which were both consistent with a chair conformation for the cyclohexane ring. The $\alpha$-orientation of $\mathrm{H}-3$ was deduced from the cross-peak of $\mathrm{H}-3$ to $\mathrm{H}-2 \mathrm{a} / \mathrm{H}_{3}-12$ and $\mathrm{H}-7$ and $\mathrm{H}-2 \mathrm{~b}$ to $\mathrm{H}-11$ and $\mathrm{H}-8$ in the NOESY spectrum, and the larger coupling constant $J=12.5 \mathrm{~Hz}$ of $\mathrm{H}-3\left(\delta_{\mathrm{H}} 4.60\right)$ with one of the $\mathrm{H}-2 \mathrm{a}$ protons $\left(\delta_{\mathrm{H}} 1.84\right)$ indicated that $\mathrm{H}-3$ was axial. Moreover, the NOESY correlation between $\mathrm{H}-4$ 


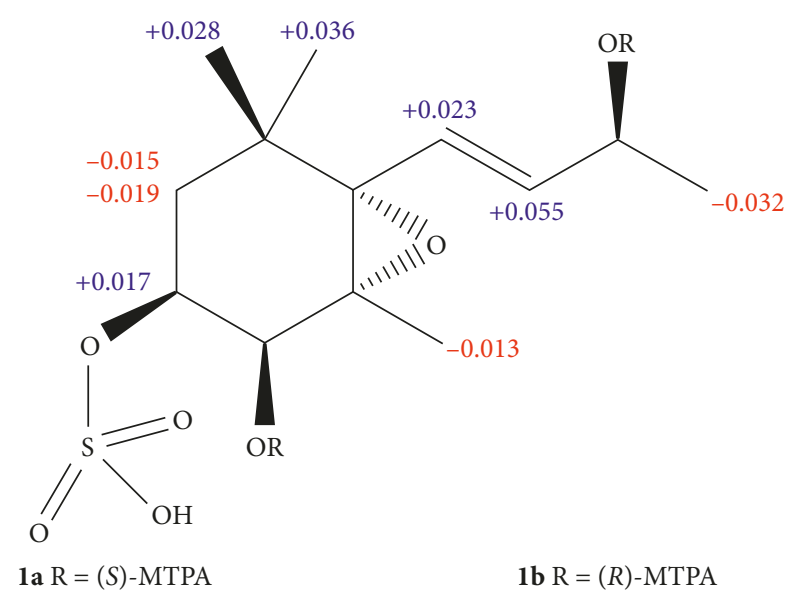

Figure 3: $\Delta \delta_{\mathrm{H}(S-R)}$ values (in ppm) for MTPA esters of $\mathbf{1}$.

and $\mathrm{H}-3$ indicated that $\mathrm{H}-4$ and $\mathrm{H}-3$ were axial bonds, which established its $\alpha$-orientation. Additionally, the coupling constants at $\mathrm{H}-3\left[\delta_{\mathrm{H}} 4.60(1 \mathrm{H}, \mathrm{ddd}, J=3.0,3.5,12.5 \mathrm{~Hz})\right]$ and $\mathrm{H}-4\left[\delta_{\mathrm{H}} 4.27(1 \mathrm{H}, \mathrm{dd}, J=1.0,3.0 \mathrm{~Hz})\right]$ of 1 were in good agreement with those of $(3 S, 4 S, 5 R, 6 S, 9 S, 7 E)$-megastigman7ene-5,6-epoxy-3,4,9-triol 9-O- $\beta$-D-glucopyranoside $\left[\delta_{\mathrm{H}}\right.$ $3.79(1 \mathrm{H}$, ddd, $J=3.0,3.0,12.0 \mathrm{~Hz}, \mathrm{H}-3)$ and $3.88(1 \mathrm{H}, \mathrm{dd}$, $J=1.0,3.0 \mathrm{~Hz}, \mathrm{H}-4)]$ recorded in the same deuterated solvent. These findings confirmed that two compounds have the same configurations at C-3 and C-4 [24]. The chemical shifts of C-5 $\left(\delta_{\mathrm{C}} 69.4\right)$ and C-6 $\left(\delta_{\mathrm{C}} 71.3\right)$ corresponded well to the similar signals observed in the ${ }^{13} \mathrm{C}$ NMR spectra (in $\left.\mathrm{CD}_{3} \mathrm{OD}\right)$ with $(3 S, 4 S, 5 R, 6 S, 9 S, 7 E)$-megastigman-7ene5,6-epoxy-3,4,9-triol 9-O- $\beta$-D-glucopyranoside $\left[\begin{array}{ll}\delta_{\mathrm{C}} & 69.7\end{array}\right.$ (C-5) and $71.6(\mathrm{C}-6)$ ] [24] and the major difference from the ${ }^{13} \mathrm{C}$ NMR spectrum (in $\mathrm{CD}_{3} \mathrm{OD}$ ) with $5 S, 6 R$ configurations of (3S, $4 S, 5 S, 6 R, 7 E, 9 S)$-5,6-epoxy-3,4,9-trihydroxy-7megastigmen-3-O- $\beta$-D-glucopyranoside (komaroveside $\mathrm{C}$ ) $\left[\delta_{\mathrm{C}} 68.2(\mathrm{C}-5)\right.$ and $\left.70.4(\mathrm{C}-6)\right]$ [25]. These data clearly indicated the presence of $5 R, 6 S$ configurations in 1 . To determine the absolute configuration of C-9 in 1, $(S)$ - and $(R)$-MTPA esters (1a and $\mathbf{1 b})$ were prepared. Significant $\Delta \delta$ values $\left(\Delta \delta=\delta_{S \text {-MTPA-ester }}-\delta_{R \text {-MTPA-ester }}\right)$ were observed for the proton signal adjacent to C-9, as shown in Figure 3. According to the rule of the modified Mosher's method [26, 27], the absolute configuration at C-9 in $\mathbf{1}$ was assigned $S$-form. On the basis of the abovementioned data, the structure of 1 was elucidated to be $\quad(3 S, 4 R, 5 R, 6 S, 9 S, 7 E)$-megastigman-5,6-epoxy-7-ene,4,9diol,3-sulfonic acid.

A molecular formula of $\mathrm{C}_{10} \mathrm{H}_{16} \mathrm{O}_{3}$ was established for wednenol (2) based on the presence of 10 signals in its ${ }^{13} \mathrm{C}$ NMR spectrum and the HRESIMS protonated molecular ion peak at $m / z 185.1170[\mathrm{M}+\mathrm{H}]^{+}$(cald. 185.1178). In the ${ }^{1} \mathrm{H}$ NMR spectrum, signals were observed for a secondary methyl group $\left[\delta_{\mathrm{H}} 1.15(\mathrm{~d}, J=6.5 \mathrm{~Hz}, \mathrm{H}-10)\right]$, two oxygenbearing methine groups $\left[\delta_{\mathrm{H}} 4.00(\mathrm{dd}, J=6.0,9.5 \mathrm{~Hz}, \mathrm{H}-2)\right.$ and 3.51 (q, $J=6.5 \mathrm{~Hz}, \mathrm{H}-9)$ ], oxygenated methylene groups [ $\delta_{\mathrm{H}} 3.95$ (ddd, $\left.J=3.0,8.0,9.5 \mathrm{~Hz}, \mathrm{H}-8 \mathrm{a}\right)$ and 4.05 (dd, $J=8.0$, $8.5 \mathrm{~Hz}, \mathrm{H}-8 \mathrm{~b})$ ], and four methylene groups (Table 1). Its ${ }^{13} \mathrm{C}$ NMR spectrum exhibited ten carbon signals, including a methyl $\left[\delta_{\mathrm{C}} 17.0(\mathrm{C}-10)\right]$, two methines $\left[\delta_{\mathrm{C}} 83.3(\mathrm{C}-2)\right.$ and
74.3 (C-9)], an oxygenated methylene $\left[\delta_{\mathrm{C}} 66.4(\mathrm{C}-8)\right]$, and four methylenes $\left[\delta_{\mathrm{C}} 37.5(\mathrm{C}-3), 29.2(\mathrm{C}-5), 30.5(\mathrm{C}-6)\right.$, and 36.0 (C-7)], suggesting that 2 was a cyclohexylethanoid derivative [28].

Analysis of the ${ }^{1} \mathrm{H}$ and ${ }^{13} \mathrm{C}$ NMR data of 2 (Table 1) suggested that this compound shares several structural similarities with cleroindicin E (3) [28], except for major differences in the resonances associated with the additional methyl and oxygenated methine groups. The ${ }^{1} \mathrm{H}-{ }^{1} \mathrm{H}$ COSY spectrum of 2 was observed to exhibit proton correlations between $\mathrm{H}-5$ and $\mathrm{H}-6$, between $\mathrm{H}-7$ and $\mathrm{H}-8$, between $\mathrm{H}-2$ and $\mathrm{H}-3$, and between $\mathrm{H}-9$ and $\mathrm{H}-10$ (Figure 2). In the HMBC spectrum, cross-peaks between $\mathrm{H}-10\left(\delta_{\mathrm{H}} 1.15\right)$ and C-4 $\left(\delta_{\mathrm{C}} 75.4\right)$, and $\mathrm{H}-10\left(\delta_{\mathrm{H}} 1.15\right)$ and C-9 $\left(\delta_{\mathrm{C}} 74.3\right)$, between $\mathrm{H}-9\left(\delta_{\mathrm{H}} 3.51\right)$ and C-3 $\left(\delta_{\mathrm{C}} 37.5\right), \mathrm{C}-4\left(\delta_{\mathrm{C}} 75.4\right)$, and C-5 $\left(\delta_{\mathrm{C}}\right.$ 29.2) clearly indicated the positions of the methyl and oxygenated methine groups. Moreover, the C- 1 resonance was shifted downfield, from $\delta_{\mathrm{C}} 75.8$ in 3 to $\delta_{\mathrm{C}} 79.4$ in 2 . The downfield shift of C-1 may be explained by the presence of a C-1-C-9 ether linkage in 2 . These findings suggested that one cyclohexylethanoid unit in 2 should have a 1,2,4trioxygenated-cyclohexylethanoid structure. Detailed analysis of the other COSY and HSQC spectra unambiguously identified the planar structure of $\mathbf{2}$ (Figure 2). In the NOESY spectrum of 2 , the doublet of doublets belonging to $\mathrm{H}-2\left[\delta_{\mathrm{H}}\right.$ $4.00(1 \mathrm{H} \mathrm{dd}, J=6.0,9.5 \mathrm{~Hz})]$ was observed, which correlated with $\mathrm{H}-3 \mathrm{a}$ and $\mathrm{H}-7 \mathrm{a}$, and the coupling constant $J=6.0 \mathrm{~Hz}$ of $\mathrm{H}-2\left(\delta_{\mathrm{H}} 4.00\right)$ with one of the $\mathrm{H}-3$ a protons $\left(\delta_{\mathrm{H}} 1.39\right)$ indicated that $\mathrm{H}-2$ was equatorial orientation. Additionally, the NOESY correlation of $\mathrm{H}-3 \mathrm{a}$ and $\mathrm{H}-9$ and their coupling constant $(J=6.5 \mathrm{~Hz})$ suggested that $\mathrm{H}-9$ was also an equatorial bond. Thus, the structure of wednenol was elucidated as 2 .

On comparison of their physical and spectroscopic data with published values, the known compounds were identified as cleroindicin E (3) [29], rengyol (4) [30], cornoside (5) [28], benzyl $\beta$-D-glucopyranoside-2-sulfate (6) [31], jaceosidin (7) [32], pomonic acid (8) [33], and pomolic acid (9) [34].

3.2. $\alpha$-Amylase and $\alpha$-Glucosidase Inhibitory Activities of Compounds 1-9. The inhibitory effects of the isolated compounds against porcine pancreas $\alpha$-amylase and yeast $\alpha$-glucosidase were evaluated in comparison with the antidiabetic acarbose. $\alpha$-Glucosidase is the key catalyzing enzyme involved in the process of carbohydrate digestion and glucose release. Inhibition of $\alpha$-glucosidase is one very effective way of delaying glucose absorption and lowering the postprandial blood glucose level, which can potentially suppress the progression of DM.

The isolated flavonoid (7) showed the most active $\alpha$-amylase and $\alpha$-glucosidase inhibitory activities with $\mathrm{IC}_{50}$ values of $112.8 \pm 15.1$ and $785.9 \pm 12.7 \mu \mathrm{g} / \mathrm{mL}$, respectively (Table 2 and Figure 4). This is in agreement with a recent report of the $\alpha$-amylase and $\alpha$-glucosidase inhibitory activities in other flavonoids [35-37]. Compounds 1, 8, and 9 showed moderate inhibitory effects against $\alpha$-amylase and $\alpha$-glucosidase, when compared with those of a standard 
TABLE 2: Inhibitory effects of selected compounds against $\alpha$-amylase and $\alpha$-glucosidase activities $\left(\mathrm{IC}_{50} \pm \mathrm{SD}, \mu \mathrm{g} / \mathrm{mL}\right)$.

\begin{tabular}{lcc}
\hline Compounds $^{\mathrm{a}}$ & $\alpha$-Amylase & $\alpha$-Glucosidase \\
\hline $\mathbf{1}$ & $436.8 \pm 28.6$ & $915.6 \pm 36.5$ \\
$\mathbf{7}$ & $112.8 \pm 15.1$ & $785.9 \pm 12.7$ \\
$\mathbf{8}$ & $420.7 \pm 25.2$ & - \\
$\mathbf{9}$ & $395.6 \pm 18.3$ & $821.4 \pm 55.2$ \\
Acarbose $^{\mathrm{b}}$ & $124.0 \pm 21.3$ & $642.6 \pm 46.4$ \\
\hline
\end{tabular}

${ }^{a}$ Compounds were tested in a set of experiments three times. For different versus control group, $P<0.05$. ${ }^{\mathrm{b}}$ Acarbose was used as a positive control. (-): no inhibition (less than 10\% inhibition).

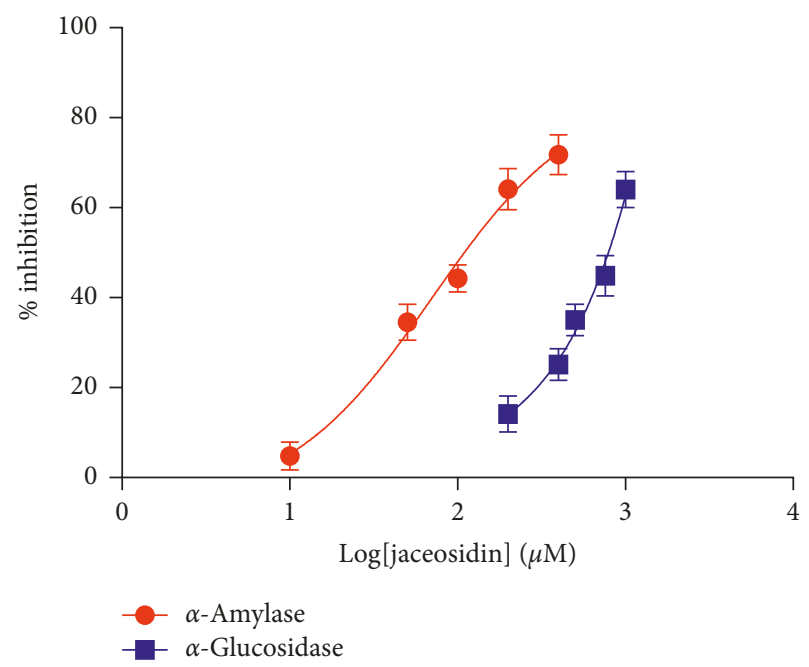

Figure 4: $\mathrm{IC}_{50 \mathrm{~S}}$ of 7 against $\alpha$-amylase and $\alpha$-glucosidase. Activity data points (absorbance) were plotted as mean $\pm \operatorname{SD}(n=3)$.

reference drug, acarbose, with $\mathrm{IC}_{50}$ values of $124.0 \pm$ $21.3 \mu \mathrm{g} / \mathrm{mL}$ (against $\alpha$-amylase) and $642.6 \pm 46.4 \mu \mathrm{g} / \mathrm{mL}$ (against $\alpha$-glucosidase). In contrast, other compounds (2-6) showed weak or did not show any effect on both enzymes. These results indicated that the megastigmane, flavonoids, and triterpenoids exhibited high inhibitory activity but were not sufficient to clarify the structureactivity relationships between derivatives. Further research is required to clarify their potential selective $\alpha$-amylase and $\alpha$-glucosidase activities.

\section{Conclusion}

In conclusion, the present work reported for the first time the $\alpha$-amylase and $\alpha$-glucosidase inhibitory effects of $W$. chinensis, in support of their ethnomedicinal use for diabetes. This report partly defines the reason on why these medicinal plants possess antidiabetic properties and could provide a scientific warrant for their application as health supplementary herbal products for diabetes treatment and prevention.

\section{Data Availability}

The data used to support the findings of this study are available from the corresponding author upon request.

\section{Conflicts of Interest}

The authors declare that there are no conflicts of interest regarding the publication of this paper.

\section{Acknowledgments}

This research was funded by the Vietnam National Foundation for Science and Technology Development (NAFOSTED) under Grant no. 104.01-2016.55.

\section{Supplementary Materials}

HRESIMS, ${ }^{1} \mathrm{H},{ }^{13} \mathrm{C}$, and 2D NMR spectra of new compounds 1-2; ${ }^{1} \mathrm{H}$ and ${ }^{13} \mathrm{C}$ NMR data of compounds 3-5 and 7. (Supplementary Materials)

\section{References}

[1] http://www.who.int/diabetes/facts/world_figures/en/index5. html.

[2] Addressing Asia's fast growing diabetes epidemic," Bulletin of the World Health Organization, vol. 95, no. 8, pp. 550-551, 2017.

[3] Y. I. Kwon, E. Apostolidis, and K. Shetty, "Inhibitory potential of wine and tea against $\alpha$-amylase and $\alpha$-glucosidase for management of hyperglycemia linked to type 2 diabetes," Journal of Food Biochemistry, vol. 32, no. 1, pp. 15-31, 2008.

[4] R. K. Campbell, J. R. White Jr., and B. A. Saulie, "Metformin: a new oral biguanide," Clinical Therapeutics, vol. 18, no. 3, pp. 360-371, 1996.

[5] A. J. Krentz and C. Bailey, "Oral antidiabetic agents: current role in type 2 diabetes mellitus," Drugs, vol. 65, no. 3, pp. 385-411, 2005.

[6] M. Ekor, "The growing use of herbal medicines: issues relating to adverse reactions and challenges in monitoring safety," Frontiers in Pharmacology, vol. 4, no. 177, pp. 1-10, 2013.

[7] A. G. Atanasov, B. Waltenberger, E.-M. Pferschy-Wenzig et al., "Discovery and resupply of pharmacologically active plant-derived natural products: a review," Biotechnology Advances, vol. 33, no. 8, pp. 1582-1614, 2015.

[8] "V. The Plant List," http://www.theplantlist.org/.

[9] The Wealth of India, A Dictionary Indian Raw Materials and Industrial Products, The Wealth of India, Raw Materials, Council of Scientific and Industrial Research, New Delhi, India, 2005.

[10] H. Wagner, B. Geyer, Y. Kiso, H. Hikino, and G. S. Rao, "Coumestans as the main active principles of the liver drugs Eclipta alba and Wedelia calendulacea," Planta Mededica, vol. 34, no. 5, pp. 370-374, 1986.

[11] F. M. Lin, L. R. Cheu, E. H. Lin, F. C. Ke, and M. J. Tsai, "Compounds from W. chinensis synergistically suppress androgen activity and growth in prostate cancer," Carcinogenesis, vol. 28, no. 12, pp. 2521-2529, 2007.

[12] C. H. Tsai, S. F. Tzeng, S. C. Hsieh et al., "Development of a standardized and effect-optimized herbal extract of Wedelia chinensis for prostate cancer," Phytomedicine, vol. 22, no. 3, pp. 406-414, 2015.

[13] A. Manjamalai and B. Grace, "Antioxidant activity of essential oils from Wedelia chinensis (Osbeck) in vitro and in vivo lung cancer bearing C57BL/6 mice," Asian Pacific Journal of Cancer Prevention, vol. 13, no. 7, pp. 3065-3071, 2012. 
[14] I. Nomani, A. Mazumder, and G. S. Chakraborthy, "Wedelia chinensis (Asteraceae)-an overview of a potent medicinal herb," International Journal of PharmTech Research, vol. 5, no. 3, pp. 957-964, 2013.

[15] W.-C. Lin, C.-C Wen, Y.-H. Chen et al., "Integrative approach to analyze biodiversity and anti-inflammatory bioactivity of Wedelia medicinal plants," PLoS One, vol. 10, no. 6, article e0129067, 2015.

[16] A. Shirwaikar, R. G. Prabhu, and S. Malini, "Activity of Wedelia calendulacea Less. in post-menopausal osteoporosis," Phytomedicine, vol. 13, no. 1-2, pp. 43-48, 2006.

[17] N. Verma and R. L. Khosa, "Effect of Costus speciosus and Wedelia chinensis on brain neurotransmitters and enzyme monoamine oxidase following cold immobilization stress," Journal of Pharmaceutical Sciences, vol. 1, no. 2, pp. 22-25, 2009.

[18] P. Murugaian, V. Ramamurthy, and N. Karmegam, "Hepatoprotective activity of Wedelia calendulacea against acute hepatotoxicity in rats," Research Journal of Agriculture and Biological Sciences, vol. 4, no. 6, pp. 685-687, 2008.

[19] T. Prakash, N. R. Rao, and A. H. M. V. Swamy, "Neuropharmacological studies on Wedelia calendulacea Less stem extract," Phytomedicine, vol. 15, no. 11, pp. 959-970, 2008.

[20] R. Kusano, S. Ogawa, Y. Matsuo, T. Tanaka, Y. Yazaki, and I. Kouno, " $\alpha$-Amylase and lipase inhibitory activity and structural characterization of acacia bark proanthocyanidins," Journal of Natural Products, vol. 74, no. 2, pp. 119-128, 2011.

[21] E. A. H. Mohamed, M. J. A. Siddiqui, L. F. Ang et al., "Potent $\alpha$-glucosidase and $\alpha$-amylase inhibitory activities of standardized 50\% ethanolic extracts and sinensetin from Orthosiphon stamineus Benth as anti-diabetic mechanism," BMC Complementary and Alternative Medicine, vol. 12, no. 176, 2012.

[22] T. T. H. Hanh, N. M. Chau, L. H. Tram et al., "Inhibitors of a-glucosidase and a-amylase from Cyperus rotundus," Pharmaceutical Biology, vol. 52, no. 1, pp. 74-77, 2014.

[23] M.S. Ali, M. Jahangir, S. S. Hussan, and M. I. Choudhary, "Inhibition of alpha-glucosidase by oleanolic acid and its synthetic derivatives," Phytochemistry, vol. 60, no. 3, pp. 295-299, 2002.

[24] Q. Yu, K. Katsunami, H. Otsuka, and Y. Takeda, "Staphylionosides A-K: megastigmane glucosides from the leaves of Staphylea bumalda DC," Chemical and Pharmaceutical Bulletin, vol. 53, no. 7, pp. 800-807, 2005.

[25] I. K. Lee, K. H. Kim, S. Y. Lee, S. U. Choi, and K. R. Lee, “Three new megastigmane glucopyranosides from the Cardamine komarovii," Chemical and Pharmaceutical Bulletin, vol. 59, no. 6, pp. 773-777, 2011.

[26] I. Ohtani, T. Kusumi, Y. Kashman, and H. Kakisawa, "Highfield FT NMR application of Mosher's method. The absolute configurations of marine terpenoids," Journal of the American Chemical Society, vol. 113, no. 11, pp. 4092-4096, 1991.

[27] J. M. Seco, E. Quiñoá, and R. Riguera, "The assignment of absolute configuration by NMR," Chemical Reviews, vol. 104, no. 1, pp. 17-118, 2004.

[28] T. Hase, Y. Kawamoto, K. Ohtani, R. Kasai, K. Yamasaki, and C. Picheansoonthon, "Cyclohexylethanoids and related glucosides from Millingtonia hortensis," Phytochemistry, vol. 39, no. 1, pp. 235-241, 1995.

[29] M. Honzumi, T. Kamikubo, and K. Ogasawara, "A stereocontrolled route to cyclohexylethanoid natural products," Synlett, vol. 1998, pp. 1001-1003, 1998.
[30] H. Abdullahi, E. Nyandat, C. Galeffi, I. Messana, M. Nicoletti, and G. B. M. Bettolo, "Cyclohexanols of Halleria lucida," Phytochemistry, vol. 25, no. 12, pp. 2821-2823, 1986.

[31] K. Ohtani, R. Kasai, K. Yamasaki et al., "Lignan glycosides from stems of Salvadora persica," Phytochemistry, vol. 31, no. 7, pp. 2469-2471, 1992.

[32] A. Tapia, J. Rodriguez, C. Theoduloz, S. Lopez, G. E. Feresin, and G. Schmeda-Hirschmann, "Free radical scavengers and antioxidants from Baccharis grisebachii," Journal of Ethnopharmacology, vol. 95, no. 2-3, pp. 155-161, 2004.

[33] D. L. Cheng and X. P. Cao, "Pomolic acid derivatives from the root of Sanguisorba officinalis," Phytochemistry, vol. 31, no. 4, pp. 1317-1320, 1992.

[34] C. Hata, M. Kakuno, K. Yoshikawa, and S. Arihara, "Triterpenoid saponin of aquifoliaceous plants.V. Ilexosides XVXIX from the barks of Ilex crenata Thunb," Chemical and Pharmaceutical Bulletin, vol. 40, no. 8, pp. 1990-1992, 1992.

[35] D. F. Pereira, L. H. Cazarolli, C. Lavado et al., "Effects of flavonoids on a-glucosidase activity: potential targets for glucose homeostasis," Nutrition, vol. 27, no. 11-12, pp. 1161-1167, 2011.

[36] A. H. Zeid, M. AliFarag, M. A. AzizHamed, Z. A. AzizKandil, R. HassanEl-Akad, and H. MohamedEl-Rafie, "Flavonoid chemical composition and antidiabetic potential of Brachychiton acerifolius leaves extract," Asian Pacific Journal of Tropical Biomedicine, vol. 7, no. 5, pp. 389-396, 2017.

[37] P. V. A. Babu, D. Liu, and E. R. Gilbert, "Recent advances in understanding the anti-diabetic actions of dietary flavonoids," Journal of Nutritional Biochemistry, vol. 24, no. 11, pp. 1777-1789, 2013. 

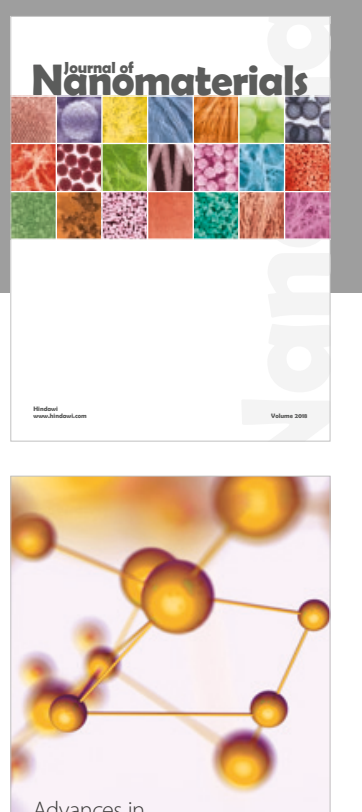

Physical Chemistry
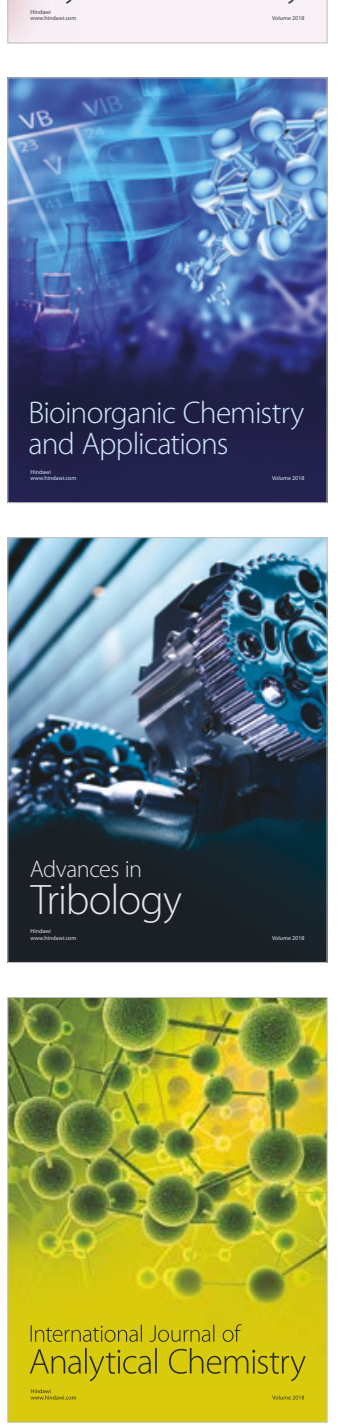

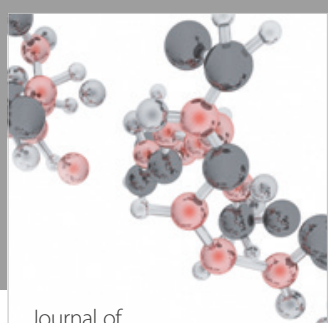

Analytical Methods

in Chemistry

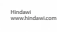

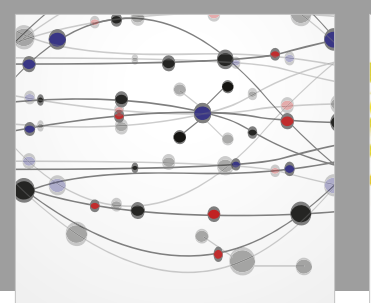

The Scientific World Journal

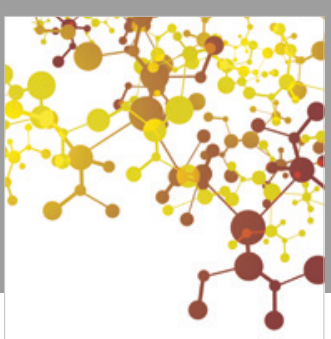

Journal of

Applied Chemistry
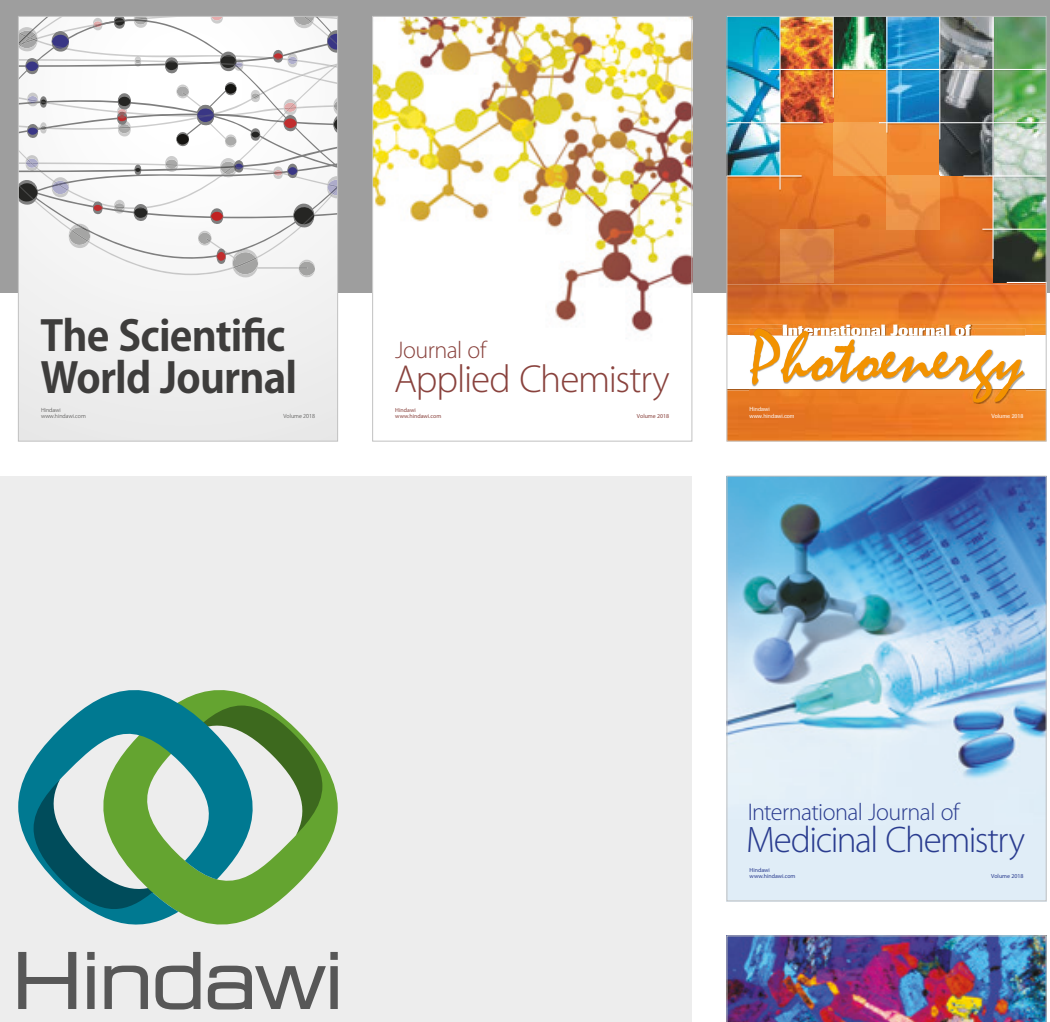

Submit your manuscripts at

www.hindawi.com
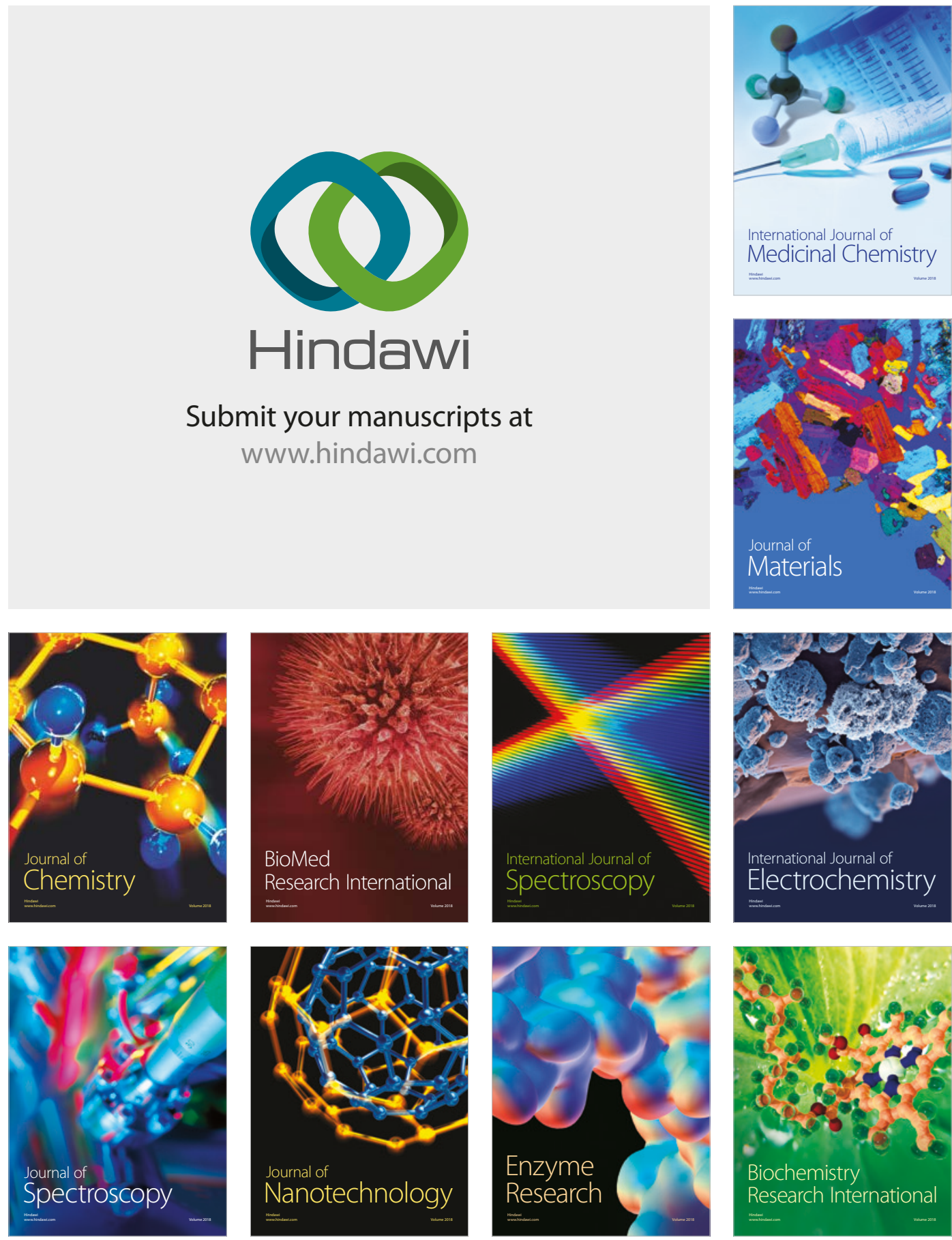
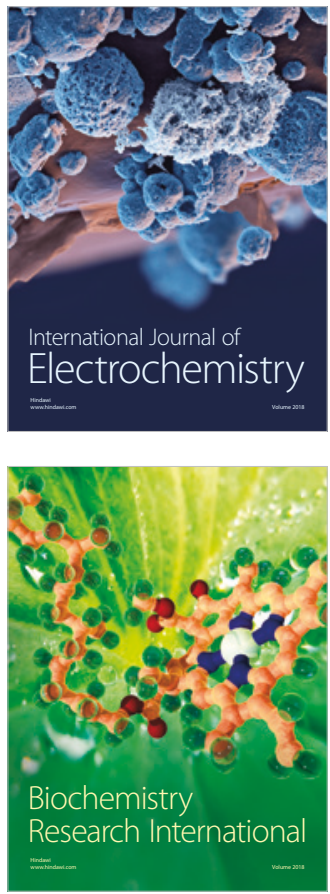